\title{
Mikołaj Labijak
}

Uniwersytet im. Adama Mickiewicza, Poznań

\section{Rozwiązania prawnoustrojowe Republiki Weimarskiej w perspektywie historycznej i porównawczej}

DOI: http://dx.doi.org/10.12775/SIT.2014.008

\section{Wprowadzenie}

Historia Republiki Weimarskiej oraz zagadnienia związane $z$ jej ustrojem są stosunkowo dobrze opracowane na gruncie literatury polskiej i zagranicznej. Nie jest więc celem niniejszego artykułu powtarzanie wypracowanych już twierdzeń, lecz wybór najciekawszych rozwiązań prawnoustrojowych i próba szerszego spojrzenia na nie, uwzględniając kontekst historyczny i porównawczy.

Rzeczona problematyka konstytucyjna przywoływana bywa w publikacjach jako tło dla innych zagadnień, a autorzy podręczników akademickich poświęcajajej często nader mało uwagi. Przyczyn takiego stanu jest kilka, jednak najistotniejszych upatrywać należy w przejściowym charakterze państwa, jakim była Republika Weimarska1. Bywa bowiem uważana za swoistą efemerydę, etap pośredni na drodze do narodowego socjalizmu². Jednakże omawiany okres kilkunastu lat nie pozostaje bez znaczenia dla historii narodu

${ }^{1}$ Zob. szerzej T. Kotłowski, Historia Republiki Weimarskiej (1919-1933), Poznań 1991, s. 7 i przywołana w przypisach literatura.

${ }^{2}$ Zob. K. Kamińska, A. Gaca, Historia powszechna ustrojów państwowych, Toruń 2011, s. 622. 
niemieckiego, a ponadto ustrój Republiki Weimarskiej uchodzi za „najbardziej demokratyczny w historii Niemiec system rządów parlamentarnych"3.

Drugim, w mojej ocenie, powodem umniejszania znaczenia Republiki Weimarskiej jest fakt, że twórcy konstytucji czerpali z przemyśleń wypracowanych w innych państwach. Według Stanisława Salmonowicza była to improwizowana demokracja, oparta na przejęciu elementów $z$ różnych modeli ustrojowych ${ }^{4}$. Jednak właśnie to jest $z$ perspektywy komparatystycznej niezwykle interesujące, ponieważ wskazuje na twórcze wykorzystanie obcych wzorców.

$Z$ powyższych powodów jest zadaniem istotnym, by choć w krótkim artykule przybliżyć ustrój Rzeszy Niemieckiej w okresie międzywojennym $z$ uwzględnieniem kontekstu państw, które stanowiły inspirację dla niemieckiego ustrojodawcy.

Nim przejdę do właściwej części opracowania, krótkiego wyjaśnienia wymaga metodologia pracy porównawczej, której elementy zostaną wykorzystane. Według definicji Romana Tokarczyka „komparatystyka polega na zestawieniu cech względnie jednorodnych przynajmniej dwóch przedmiotów w celu stwierdzenia występujących między nimi identyczności, podobieństw iróżnic”. tej definicji oparta jest również komparatystyka prawnicza ${ }^{6}$. Na potrzeby niniejszego artykułu wykorzystam pragmatyczne podejście do prawa porównawczego na gruncie prawa konstytucyjnego, polegające na zestawieniu konkretnych instytucji czy rozwiązań.

${ }^{3}$ K. Krasowski et al., Historia ustroju państwa, Poznań 2002, s. 284. Warto jednak zaznaczyć, że owa demokratyczna konstytucja nie była należycie przestrzegana ani w czasach Republiki Weimarskiej, ani w III Rzeszy (gdzie formalnie nadal obowiązywała).

${ }^{4}$ S. Salmonowicz, Prusy. Dzieje państwa i społeczeństwa, Warszawa 2004, s. 413.

${ }^{5}$ R. Tokarczyk, Wprowadzenie do komparatystyki prawniczej, Lublin 1996, s. 27.

${ }^{6}$ Zob. R.R. Ludwikowski, Prawo konstytucyjne porównawcze, Toruń 2000, s. 19-27 i przywoływana tam literatura. Zob. także szerzej o metodzie prawno-porównawczej: B. Banaszak, Porównawcze prawo konstytucyjne współczesnych państw demokratycznych, Warszawa 2012, s. 40-43. 


\section{Rys historyczny}

Historia Republiki Weimarskiej rozpoczyna się w ostatnich miesiącach I wojny światowej, jesienią 1918 roku. Wśród społeczeństwa niemieckiego pojawiły się tendencje rewolucyjne dążące do zakończenia zmagań na frontach i obalenia cesarskiego porządku. Radykalne nastawienie potęgowały również przenikające wpływy bolszewickie. Ruch antywojenny aktywował się jednak już wcześniej, bo w roku 1916, kiedy to na jego czele stanęła tzw. Grupa Spartakusa ${ }^{7}$. W praktyce bunt rozpoczął się 3 listopada 1918 roku w wyniku lokalnego powstania marynarzy w Kilonii, które uległo eskalacji. Władzę w miastach zaczęły obejmować Rady Robotnicze i Żołnierskie. Cesarz Wilhelm II zmuszony był abdykować i opuścić $\mathrm{kraj}^{8}$. W Berlinie 9 listopada 1918 roku proklamowano republikę. Wszystkie dynastie rządzące $\mathrm{w}$ pozostałych państwach niemieckich zostały pozbawione tronu. Państwo targane wewnętrznymi problemami skapitulowało i 11 listopada władze podpisały zawieszenie broni. Taki rozwój sytuacji jest krytycznie oceniany przez Hagena Schulzego, który uważa, że „pierwsza niemiecka demokracja nie zrodziła się z własnej siły partii i parlamentów, lecz stanowiła osta-

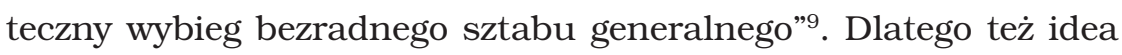
rządów demokratycznych pojawiła się w nieodpowiednim momencie historycznym. Pokój zawarto 28 czerwca 1919 roku $^{10}$.

Nowy tymczasowy rząd w styczniu 1919 roku ogłosił wybory do Zgromadzenia Narodowego, którego obrady odbywały się w Wei-

${ }^{7}$ Grupa Spartakusa (początkowo Związek Spartakusa) to rewolucyjna organizacja niemiecka założona przez lewicowych socjaldemokratów: R. Luksemburg, K. Liebknechta, J. Marchlewskiego i F. Mehringa. Impulsem do powstania związku było wypowiedzenie wojny Imperium Rosyjskiemu w 1914 roku.

${ }^{8}$ Po abdykacji cesarza władzę objął prowizoryczny rząd, Rada Pełnomocników Ludowych, złożony głównie $z$ prawicowych socjaldemokratów. Wojsko poparło rząd w celu stłumienia rewolucji.

${ }^{9}$ H. Schulze, Państwo i naród $w$ dziejach Europy, tłum. D. Lachowska, Warszawa 2012, s. 257.

${ }^{10}$ Zob. szerzej o rokowaniach pokojowych i sporach o treść traktatu: A. Czubiński, Wybrane problemy historii Niemiec XIX i XX wieku, Poznań 1992, s. $120-139$. 
marze. Właśnie ta mała miejscowość stała się symbolem nowego ustroju. Weimar wybrano $z$ chęci odcięcia się od pruskiej dominacji i nawiązania do tradycji kulturalnej ${ }^{11}$. Berlin był też niebezpieczny ze względu na rewolucyjną atmosferę. Zgromadzenie Narodowe powołało prezydenta (został nim Friedrich Ebert) i koalicyjny Tymczasowy Rząd. Warto podkreślić, że był to pierwszy w historii Niemiec rząd wyłoniony „przez demokratycznie wybrany organ przedstawicielski ogółu ludności”" ${ }^{12}$. Kilka miesięcy później, 5 sierpnia 1919 roku, uchwalono nową konstytucję ${ }^{13}$. Oficjalna nazwa państwa brzmiała: Rzesza Niemiecka, jednak w nauce i praktyce utrwaliła się nazwa Republika Weimarska. Wskazuje ona na zerwanie $z$ tradycją Rzeszy zmajoryzowanej przez Prusy i podkreśla republikański charakter nowego państwa.

Historia ustrojów państwowych dwudziestolecia międzywojennego dzieli ustroje demokratyczne na tzw. stare i nowe demokracje ${ }^{14}$. Do „starych” należą państwa, w których tradycje władzy demokratycznej sięgają czasów sprzed I wojny światowej. W roku 1918 uznały one, że „wojna wykazała wyższość instytucji demokratycznych nad biurokratyczno-militarnymi, wymagają więc one doskonalenia, a nie jakichś gruntownych zmian" ${ }^{15}$. Państwa te nie borykały się z tak ogromnymi problemami jak „nowe” demokracje (np. Austria, Republika Weimarska). Łatwiej udało im się naprawić powojenne straty. Także wielki kryzys lat 30. jedynie je osłabił, ale nie doprowadził do zakwestionowania zasadności rządów demokratycznych, choć i tam pojawiały się ruchy radykalne i doszło do zwiększenia zakresu interwencjonizmu państwowego. Inaczej było w państwach „nowej” demokracji, gdzie systemy załamywały się, ustępując ustro-

11 Zob. S. Grodziski, Porównawcza historia ustrojów państwowych, Kraków 1998, s. 262. Z Weimarem związane są takie postacie jak: Jan W. Goethe, Fryderyk Schiller, Fryderyk Nietzsche, czy Jan S. Bach. Tu także działał ruch artystyczny Bauhaus.

12 K. Kamińska, A. Gaca, op.cit., s. 618.

${ }^{13}$ Prezydent podpisał konstytucję 11 sierpnia 1919 roku. Zanim ustawa zasadnicza weszła w życie, władze funkcjonowały, opierając się na ustawie o tymczasowej władzy w Rzeszy z 10 lutego 1919 roku.

14 Podział przytaczany za J. Baszkiewicz, Powszechna historia ustrojów państwowych, Gdańsk 2007.

${ }^{15}$ Zob. ibidem, s. 343. 
jom autorytarnym i totalitarnym. Przyczyną była nieugruntowana tradycja demokracji parlamentarnej, przez co państwa te nie radziły sobie $z$ kryzysem politycznym i gospodarczym ${ }^{16}$. Według Thomasa Mergela Republika Weimarska wypada na tym tle korzystnie. Zaskakujące jest bowiem to, że demokracja w Niemczech ostała się dłużej niż w innych państwach, np. Czechosłowacji czy Polsce. Dyktatura jako forma sprawowania rządów była popularna w tym okresie, o czym świadczy fakt, że nawet Francja stanęła przed taką możliwością w 1934 roku. Także przykład fali demokratyzacji po II wojnie światowej pokazuje, że „demokracji trzeba się nauczyć, a to wymaga czasu"17.

\section{Konstytucja Republiki Weimarskiej}

\subsection{Ogólna charakterystyka}

Zasadniczym problemem powojennych Niemiec było uchwalenie demokratycznej konstytucji. W tym celu zwołano w Weimarze Zgromadzenie Narodowe, które uchwaliło konstytucję Rzeszy Niemieckiej. Projekt przygotowano bardzo szybko, gdyż uważano, że uchwalenie konstytucji przyczyni się do ustabilizowania sytuacji w kraju. Za podstawę ustrojową przyjęto obalenie monarchii i wprowadzenie republiki parlamentarnej ${ }^{18}$.

Konstytucja niemiecka czerpała $z$ doświadczeń innych państw. Była oparta w dużej mierze na wzorach liberalnych demokracji, zwłaszcza III Republiki Francuskiej ${ }^{19}$ (kolegialna rada ministrów,

${ }^{16}$ Zob. J. Stembrowicz, Rzad $w$ systemie parlamentarnym, Warszawa 1982, s. 89.

17 T. Mergel, Dictatorship and Democracy (1918-1939), w: The Oxford Handbook of Modern German History, red. H.W. Smith, Oxford 2011, s. 435-437.

18 Wobec twórców konstytucji pojawiły się pewne zarzuty, tzn. myślenie pozytywistycznymi kategoriami oraz brak znajomości politycznych realiów, co było szczególnie istotne przy wprowadzeniu takiej formy rządów. Zob. J. Stembrowicz, op.cit., s. 87, przyp. 4 i przywołana tam literatura.

19 Zob. K. Krasowski et al., op.cit., s. 281. Republika Weimarska nie jest tu wyjątkiem: „Doświadczenia francuskiej republiki parlamentarnej odegrały 
republika parlamentarna, sądownictwo administracyjne), Stanów Zjednoczonych (republika prezydencka, system federalny) i Wielkiej Brytanii. Ponadto zauważalne są wpływy konstytucji Konfederacji Szwajcarskiej z lat 1848 i 1874 (referendum ludowe, inicjatywa ludowa) oraz konstytucji niemieckiej z 1849 roku (zasada federalizmu, dwuizbowa władza ustawodawcza). Także inne „nowe” demokracje korzystały $z$ cudzych doświadczeń ${ }^{20}$. $Z$ czasem sama konstytucja Republiki Weimarskiej zaznaczyła swój wpływ (np. w konstytucji Finlandii z 1919 roku czy Hiszpanii z 1931 roku). Silne oddziaływanie widoczne jest w konstytucjach państw bałtyckich (Litwa, Łotwa, Estonia). Jak pisze Piotr Łossowski, „bezsprzecznie największy wpływ na konstytucję Łotwy i Litwy wywarła ustawa zasadnicza republiki weimarskiej” ${ }^{21}$. Konstytucja weimarska uchodziła „za ostatnie słowo prawodawstwa konstytucyjnego" ${ }^{22}$. Dla przykładu łotewska komisja konstytucyjna w 1922 roku korzystała nawet z protokołów posiedzeń komisji konstytucyjnej Republiki Weimarskiej, przez co wykorzystano część postanowień, które były dyskutowane, ale nie znalazły się w ostatecznym brzmieniu konstytucji weimarskiej ${ }^{23}$. Pomimo tak ogromnego wpływu konstytucja łotewska nie jest ścisłą kopią weimarskiej ${ }^{24}$.

Jedną z podstawowych zasad konstytucyjnych jest zasada suwerenności ludu (narodu). Wyrażała się ona już w preambule konstytucji: „Lud niemiecki, zjednoczony w swych szczepach i ożywiony wolą

dużą rolę w Europie po I wojnie światowej. [...] W konstytucjach wielu tych republik oparto się na wzorach III Republiki”. M. Sczaniecki, Powszechna historia państwa i prawa, Warszawa 2003.

${ }^{20}$ Zob. porównawczy przegląd rozwiązań przyjętych w państwach „nowej” demokracji: T. Maciejewski, Historia powszechna ustroju i prawa, Warszawa 2011, s. 769-779.

${ }^{21}$ P. Łossowski, Kraje bałtyckie na drodze od demokracji parlamentarnej do dyktatury (1918-1934), Wrocław-Warszawa-Kraków-Gdańsk 1972, s. 22.

22 A. Švābe, Agrārā reforma, w: Latuija 20 gados, Ryga 1938, s. 223, cyt. za: P. Łossowski,op.cit.

${ }^{23}$ Zob. szerzej P. Łossowski, op.cit., s. 22-23 i przywołana tam literatura. Zapożyczenia były krytykowane przez posłów prawicy, zauważalne było bowiem przejmowanie całych postanowień oraz samego układu tekstu. Krytyka obecna była również na Litwie ze strony Bloku Chrześcijańsko-Demokratycznego.

${ }^{24}$ P. Kierończyk, Państwo łotewskie. Geneza i ustrój konstytucyjny, Gdańsk 2008, s. $73-74$. 
odnowienia i utwierdzenia swej Rzeszy w wolności i sprawiedliwości, służenia pokojowi wewnętrznemu i zewnętrznemu oraz popierania społecznego postępu, nadał sobie niniejszą Konstytucję"25. Jest to zwrot, biorąc pod uwagę, że konstytucja z 1871 rokubyła wyrazem wspólnej woli władców poszczególnych państw składających się na związek ${ }^{26}$. Zauważalne jest, że cała konstytucja wyraża dążenie do podkreślenia roli narodu, a nie państwa ${ }^{27}$. Rozszerzono także katalog praw i wolności obywatelskich, wprowadzając liczne prawa socjalne i ekonomiczne, jak np. wolność osobistą, równość wobec prawa, prawo swobodnego uczestnictwa w życiu społecznym, możliwość tworzenia związków i stowarzyszeń (w tym zrzeszeń pracowników), swobodę sumienia i wyznania czy ochronę własności. Wolność sumienia i wyznania uregulowane w art. 135 i 136 konstytucji zagwarantowane były dodatkowo przez postanowienie o braku religii państwowej (art. 137), co było wówczas zabiegiem nieczęstym, a powtórzonym np. w konstytucji Estonii z 1920 roku.

Ustrój opierał się na trójpodziale władzy i zasadzie podmiotowości jednostki. Warte podkreślenia są też elementy demokracji bezpośredniej (referenda ludowe). Instytucja referendum nadawała Republice Weimarskiej charakter demokratycznej republiki ludowej $^{28}$. $Z$ tych i innych powodów konstytucja weimarska uchodzi za jedną $z$ najbardziej postępowych w międzywojniu ${ }^{29}$. Szeroki katalog praw był odpowiedzią na mało liberalny wymiar ustroju II Rzeszy ${ }^{30}$.

${ }^{25}$ Zob. A. Gulczyński et al., Historia państwa i prawa. Wybór tekstów źródłowych, Poznań 2002, s. 225. Co ciekawe, również w preambule konstytucji Estonii z 1920 roku, powtórzonej w brzmieniu z 2007 roku, odnaleźć można odwołanie do pojęcia społecznego postępu: „opiera się na wolności, sprawiedliwości i prawie, które jest ostoją wewnętrznego i zewnętrznego pokoju oraz rękojmią społecznego postępu i ogólnej korzyści dla obecnych i przyszłych pokoleń" (tłum. A. Puu).

${ }^{26}$ Zob. G. Górski, S. Salmonowicz, Historia ustrojów państw, Warszawa 2001, s. 640.

${ }^{27}$ G. Mann, Niemieckie dzieje $w$ XIX i XX wieku, tłum. A. Kopacki, Olsztyn 2007, s. 377.

${ }^{28}$ K. Krasowski et al., op.cit., s. 281.

${ }^{29}$ Ibidem, s. 280.

${ }^{30}$ A. Dziadzio, Koncepcja państwa prawa $w$ XIX w. Idea i rzeczywistość, „Czasopismo Prawno-Historyczne” 2005, t. 57, s. 177-201. 
W praktyce jednak katalog ten był fikcją, ponieważ brakowało przepisów umożliwiających wcielenie go w życie, a ponadto elity sprawujące władzę popierały tendencje antydemokratyczne ${ }^{31}$. Gwarantem przestrzegania praw obywatelskich konstytucja czyniła parlament, tak jak w II Rzeszy, przez co uważa się, że „konstytucja weimarska nie zadbała o należytą rękojmię praw obywatelskich"32.

Aby przezwyciężyć obecną w II Rzeszy niezależność egzekutywy od legislatywy w zakresie polityki wewnętrznej i zagranicznej, wprowadzono rządy parlamentarne. Miało to doprowadzić do odcięcia od źródeł imperialistycznej polityki II Rzeszy ${ }^{33}$.

W celu zapewnienia trwałości zasad ustrojowych zapewniono utrudniony tryb zmiany konstytucji, dlatego uchodzi ona za „sztywną"34. Zmiany można było dokonać kwalifikowaną większością $2 / 3$ głosów przy kworum $2 / 3$ ustawowej liczby posłów lub na drodze referendum, jeśli zmianę poprze większość społeczeństwa. Analogiczne rozwiązanie, $z$ pominięciem jednak referendum, przewiduje konstytucja Łotwy z 1922 roku $^{35}$.

\subsection{Praktyka konstytucyjna}

System rządów parlamentarnych w Republice Weimarskiej nie rozwinął się właściwie. Choć konstytucja utrzymana była na wysokim poziomie legislacyjnym, to nie sprawdziła się w kryzysowych czasach. Jest to znakomity przykład tego, że demokracji nie wystarczy

${ }^{31}$ Zob. K. Kamińska, A. Gaca, op.cit., s. 624. Zjawisko charakterystyczne dla zmieniających się ustrojów - na scenie politycznej obecne są te same osoby, panują dawne zwyczaje i przekonania, co utrudnia wprowadzanie gruntownych zmian. Por. I. Jaworski, Zarys powszechnej historii państwa i prawa, Warszawa 1996, s. 368.

32 A. Dziadzio, op.cit., s. 177-201.

33 Ibidem.

${ }^{34}$ Tradycyjnie w doktrynie prawa konstytucyjnego konstytucje dzieli się na „sztywne” i „elastyczne”. Systematykę tę wprowadził James Bryce. Zob. J. Bryce, Constitutions, Oxford 1905, s. 3-94.

35 Zob. art. 76 Konstytucji łotewskiej: „Sejm może zmienić Konstytucję na posiedzeniu, w którym uczestniczy co najmniej dwie trzecie członków Sejmu. Zmiany uchwalane są w trzech czytaniach większością nie mniejszą niż dwóch trzecich głosów obecnych deputowanych" (tłum. L. Gołubiec). 
tylko dobre prawo, ale potrzebna jest wola, by wdrażać to prawo demokratyczną drogą ${ }^{36}$. Nauka wskazuje na trzy okresy praktyki konstytucyjnej ${ }^{37}$.

Lata 1919-1923 to okres koalicji większościowych. Sytuacja, w której partie dysponowały większością parlamentarną, sprowadzała rolę prezydenta do funkcji mediacyjnych. Koalicje bywały też często niestabilne, ścierały się w nich różne siły polityczne i społeczne, co powodowało częste przesilenia i kryzysy rządowe.

Drugi okres to lata 1923-1930, kiedy to charakterystyczne stało się istnienie gabinetów mniejszościowych. Rozpad koalicji większościowych nastąpił po upadku rządu Gustava Stresemanna. Kolejne gabinety nie miały poparcia większości i były tylko tolerowane. W efekcie prowadziło to do wzrostu znaczenia prezydenta, który w latach 1924-1932 sześciokrotnie rozwiązywał Reichstag ${ }^{38}$. Szczególnie widoczne było to podczas kadencji Paula von Hindenburga.

Trzeci okres, trwający w latach 1930-1933, to czasy gabinetów prezydenckich, a nawet osobistych rządów prezydenta ${ }^{39}$. Prezydent powoływał zaufane gabinety bez udziału parlamentu. Fakt ten pozwalał swobodnie funkcjonować rządom, a parlament czynił bezradnym, bowiem uchwalając wotum nieufności, musiałby liczyć się $z$ rozwiązaniem przez prezydenta i ogłoszeniem nowych wyborów.

${ }^{36}$ Zob. T. Mergel, op.cit., s. 435-436.

37 Periodyzację przytaczam za: M. Wąsowicz, Historia ustroju państw zachodu. Zarys wykładu, Warszawa 2007, s. 229-230. Warto zauważyć, że okresy praktyki konstytucyjnej pokrywają się czasowo z etapami historii gospodarczej Republiki Weimarskiej (lata 1918-1923 to czas inflacji, lata 1924-1929 to czas racjonalizacji, a lata 1929-1933 to czas załamania gospodarczego). Zob. E.D. Weitz, Niemcy weimarskie. Nadzieje i tragedia, tłum. A. Czwojdrak, Kraków 2011, s. 119-132.

${ }^{38}$ Zob. szerzej J. Stembrowicz, op.cit., s. 98.

${ }^{39}$ W urzędzie prezydenta upatrywano kontynuacji II Rzeszy, dlatego już współcześni mówili o „ersatzu cesarza” (Ersatzkaiser) lub „cesarzu zastępczym”. Podobnie było w III Republice Francuskiej, gdzie kompetencje prezydenta porównywalne były z kompetencjami króla w okresie monarchii lipcowej. Spotkać można stanowisko, że „w swoim rdzeniu, republika była okaleczonym i osłabionym cesarstwem - bez cesarza”. To uzasadnia poszukiwanie cesarskiej tradycji w osobie prezydenta. Zob. G. Mann, op.cit., s. 445. 
Dlatego realna władza spoczywała w rękach głowy państwa. Jest to przejaw „rozkładu demokracji parlamentarnej” 40 . Ciekawe jest w tym kontekście stwierdzenie wypowiedziane przez łotewskiego socjaldemokratę Feliksa Cielensa w dyskusji komisji konstytucyjnej na temat roli prezydenta w ustroju Łotwy w 1921 roku. Stwierdził on bowiem, że „przykład Niemiec nie jest przekonujący. Teraz prezydentem jest demokrata Ebert. Ale gdyby np. na prezydenta wybrany został Hindenburg, to ulotniłaby się nie tylko konstytucja weimarska, lecz i cała republika niemiecka" ${ }^{41}$.

Praktyka konstytucyjna Republiki Weimarskiej przypomina rozwój parlamentaryzmu w III Republice Francuskiej. Tam również rządy były niestabilne, a koalicje szybko rozpadały się ze względu na duże rozdrobnienie partyjne, często następowały przesilenia rządowe paraliżujące politykę. Mimo że Francja obrała klasyczną drogę rządów parlamentarnych wzorem Anglii, to na przestrzeni lat system zaczął funkcjonować inaczej ${ }^{42}$. Podobne zjawisko można było zaobserwować w Republice Weimarskiej, gdzie widoczna była ewolucja od modelu rządów parlamentarnych do modelu rządów autorytarnych (na co wpływ miały tendencje monarchistyczne).

Praktyka konstytucyjna była zbyt krótka, by system mógł się sprawdzić, dlatego stosowanie konstytucji było w ocenie historyków „sekwencją rozwiązań doraźnych, które tak naprawdę nikogo nie zadowalały" 43 .

\section{Ustrój polityczny}

\subsection{Struktura państwa}

W czasie prac nad konstytucją jednym $z$ podstawowych problemów było nadanie kształtu państwu ogólnoniemieckiemu. Wywiązał się na tym tle spór federalistów $z$ unitarystami. Równie istotne było za-

${ }^{40}$ K. Krasowski et al., op.cit., s. 284.

${ }^{41}$ Cyt. za: P. Łossowski, op.cit., s. 23-24.

${ }^{42}$ Zob. szerzej I. Jaworski, op.cit., s. 366-368.

${ }^{43}$ D. Peukert, Republika Weimarska. Lata kryzysu klasycznego modernizmu, tłum. B. Ostrowska, Warszawa 2005, s. 53. 
bezpieczenie ustroju przed hegemonią Prus, wynikającą z praktyki ustrojowej II Rzeszy, a uważaną za główną przyczynę niemieckiej klęski wojennej. Taką drogę obrał Tymczasowy Rząd, sugerując, że należy „stare, na wskroś reakcyjne Prusy możliwie jak najbardziej przekształcić w demokratyczną część składową jednolitej republiki”44. Profesor Hugo Preuss był twórcą projektu konstytucji zakładającego istnienie państwa unitarnego, w którym dawne państwa związkowe uzyskałyby status autonomicznych prowincji. Prusy planowano podzielić na kilka prowincji o statusie równym innym. Ten projekt nie zyskał poparcia. Zyskał je dopiero kolejny projekt ${ }^{45}$. Ostatecznie Niemcy stały się republika federalną, w skład której wchodziło 21 republik zwanych krajami (Länder) ${ }^{46}$. Prusy formalnie pozbawiono przodującej roli, lecz „w praktyce nie uległa znacznemu ograniczeniu po 1919 r.”47. Ograniczeniu uległ stopień samodzielności podmiotów wchodzących w skład federacji. Nominalnie nie były to już państwa tworzące związek jak w konstytucji II Rzeszy Niemieckiej z 1871 roku $^{48}$. W efekcie poszczególne kraje związkowe utraciły podmiotowość prawa międzynarodowego.

Ustroje krajów związkowych oparte były na zasadach republikańskich i parlamentarnych. Kraje te przyjęły własne konstytucje. Na czele każdego $z$ nich stał prezydent. Władzę ustawodawczą sprawował jednoizbowy parlament ${ }^{49}$ wybierany w czteroprzymiotnikowych wyborach (powszechnych, równych, tajnych i bezpośrednich). Kraje te były ponadto zobowiązane do zapewnienia wszystkim grupom ludności równego prawa wyborczego do zgromadzeń reprezenta-

${ }^{44}$ Zob. M. Sczaniecki, op.cit., s. 417.

${ }^{45}$ Projekt końcowy przygotowany został przez 28-osobową Komisję Konstytucyjną. Zob. K. Kamińska, A. Gaca, op.cit., s. 618.

${ }^{46}$ Liczba krajów członkowskich w porównaniu z II Rzeszą uległa zmniejszeniu z 26 do 21, a później do 18. Oprócz tego nadal istniały relikty terytorialne I Rzeszy w postaci wolnych miast (Brema, Hamburg, Lubeka), a także kilku bardzo małych republik (Anhalt, Lippe). Dodatkowo terytoria niektórych krajów pozostawały rozbite na niegraniczące ze sobą części.

47 Zob. G. Górski, S. Salmonowicz, op.cit., s. 640.

${ }^{48} \mathrm{~W}$ art. 1 tejże konstytucji sformułowano następujące słowa: „Terytorium Związku składa się z państw [...]”. Zob. A. Gulczyński et al., op.cit., s. 219.

49 Tylko w Prusach parlament pozostał dwuizbowy. 
cyjnych, a także wprowadzały zasadę odpowiedzialności krajowych władz wykonawczych przed przedstawicielstwem ludowym.

Ze strukturą terytorialną państwa ściśle wiąże się podział kompetencji pomiędzy Rzeszę a republiki związkowe. Wiele nowych, ważnych uprawnień uzyskały władze centralne, pomimo federacyjnego charakteru państwa. Artykuł 6 konstytucji wprowadza pojęcie wyłącznych kompetencji prawodawczych Rzeszy ${ }^{50}$, do których należały: sprawy zagraniczne i polityka wobec kolonii ${ }^{51}$; obywatelstwo (przynależność państwowej), migracje ludności i ekstradycje; organizacja i funkcjonowanie sił zbrojnych Rzeszy; system monetarny, cło, budżet federacji oraz wolność obrotu gospodarczego; poczta i telekomunikacja. Ponadto mogły do nich należeć sprawy z zakresu tzw. ustawodawstwa konkurencyjnego (alternatywnego) ${ }^{52}$ : prawo cywilne, karne i procedury; regulacje dotyczące funkcjonowania prasy, stowarzyszeń oraz wolności zgromadzeń; kwestie prawa pracy, ubezpieczeń społecznych oraz organizacji przedstawicielstw zawodowych; sprawy przemysłu i górnictwa; kwestie żeglugi morskiej, rzecznej i śródlądowej oraz komunikacji lądowej i powietrznej. Jeśli Rzesza nie skorzystała $z$ tych uprawnien, to przechodziły one na ustawodawstwa krajowe. Ustawodawstwo Rzeszy mogło też wkraczać w rozwiązania ustawodawcze poszczególnych krajów (art. 12), przy czym obowiązywała supremacja prawa Rzeszy, tzn. miało ono pierwszeństwo przed prawem krajowym (art. 13). Ponadto konstytucja Republiki była nadrzędna wobec pozostałych konstytucji i ustaw, co zaczerpnięto z ustroju Stanów Zjednoczonych ${ }^{53}$. Prowadziło to $\mathrm{w}$ praktyce do ograniczania suwerenności poszczególnych krajów członkowskich ${ }^{54}$. W przypadku konfliktu sprawę rozpatrywał Najwyższy Trybunał Państwowy Rzeszy Niemieckiej (zwany też Trybunałem Stanu dla Rzeszy Niemieckiej - Staatsge-

${ }^{50}$ Katalog ten był szerszy w stosunku do konstytucji z 1871 roku.

${ }^{51} \mathrm{Na}$ mocy traktatu wersalskiego Niemcy utraciły wszystkie kolonie zdobyte w czasach II Rzeszy, jednak nowa konstytucja w art. 2 dawała możliwość przyłączania nowych terytoriów „w drodze ustawy Rzeszy”.

52 M. Klementowski, Powszechna historia ustroju, Warszawa 2012, s. 544.

${ }^{53}$ Ibidem, s. 367. W Stanach Zjednoczonych doktryna supremacji rozwijana była przez Aleksandra Hamiltona.

${ }^{54}$ Zob. K. Kamińska, A. Gaca, op.cit., s. 619. 
richtshoffürdas Deutsche Reich) ${ }^{55}$. Sprawy wewnętrzne należały do krajów, które mogły swobodnie i suwerennie decydować o administracji, policji, sądownictwie, szkolnictwie, kwestiach dotyczących kultury i nauki.

\subsection{Organy władzy państwowej}

\subsubsection{Władza ustawodawcza}

Władza ustawodawcza sprawowana była w Republice Weimarskiej przez dwuizbowy parlament: Sejm Rzeszy (Reichstag) i Radę Rzeszy (Reichsrat). Sejm wyłaniany był na czteroletnią kadencję w pięcioprzymiotnikowych wyborach (powszechnych, równych, bezpośrednich, tajnych i proporcjonalnych) ${ }^{56}$ oraz stanowił reprezentację ludu niemieckiego. Cenzus wieku obniżono do lat 20 i po raz pierwszy przyznano prawa wyborcze kobietom, co uważa się za sukces demokracji po roku 1918. Oprócz Republiki Weimarskiej tą droga poszły także państwa, takie jak: Austria, Holandia, Szwecja czy Wielka Brytania. Przeciwna była natomiast Francja ${ }^{57}$ (dołączyła dopiero w roku 1945, a najpóźniej zrobiła to Szwajcaria - w 1971 roku).

$Z$ kolei Rada Rzeszy składała się z przedstawicieli poszczególnych krajów związkowych, w liczbie proporcjonalnej do liczby mieszkańców $^{58}$. Reprezentantów mianowały rządy krajowe spośród swoich członków. Pozycja prawna obu izb była zróżnicowana. Organem ustawodawczym miał być Sejm Rzeszy, a Rada miała sprawować

55 J. Wąsicki, Rzesza a kraje niemieckie w 1914-1949, Poznań 1977, s. 148.

${ }^{56}$ Zasada proporcjonalności rodziła wśród partii politycznych konieczność walki o głosy wyborców w całym kraju, co miało jednoczyć nowe państwo. Jednocześnie wskazuje się, że system proporcjonalny sprawdza się w warunkach politycznego pokoju i społecznej akceptacji reguł działania partii. Te warunki nie były spełnione w Republice Weimarskiej. Zob. G.A. Craig, Germany 1866-1945, Oxford 1981, s. 416.

57 O przyczynach tego stanu zob. J. Baszkiewicz, op.cit., s. 343.

58 Aby ograniczyć pozycję Prus, które były największym z krajów niemieckich, zaznaczono, że żaden kraj nie może mieć ponad 40\% ogólnej liczby reprezentantów. Przyjęto też zasadę, że jeden reprezentant przypada na ma przypadać na każdy milion mieszkańców, przy czym każdy kraj musi mieć przynajmniej jednego delegata. Rozwiązanie to nazywane jest „regułą antypruską” (clausulaantiborussica). 
funkcję kontrolną ( $w$ tym celu wyposażona była w prawo weta zawieszającego wobec ustaw Sejmu). Rada posiadała też uprawnienie do nadzorowania administracji Rzeszy. Jej pozycja była słabsza niż w okresie poprzedniego ustroju.

Sejm zbierał się na sesje zwykłe dwa razy w roku. Decyzje podejmowane były zwykłą większością głosów. Inicjatywa ustawodawcza przysługiwała posłom oraz rządowi Rzeszy. Inicjatywa rządowa ograniczona była koniecznością uzyskania aprobaty Rady Rzeszy. W przypadku wystąpienia rozbieżności rząd przedkładał Sejmowi projekt wraz ze stanowiskiem Rady. Rząd zobligowany był też wnosić do Sejmu projekty Rady, nawet jeśli sam ich nie popierał. Sejm mógł odrzucić weto zawieszające Rady, gdy ponownie przyjął ustawę większością $2 / 3$ głosów. Wówczas ustawa była ogłaszana mimo sprzeciwu ze strony Rady.

Kontrolę ustawodawstwa stanowiła też instytucja referendum. Prezydent Rzeszy mógł odwołać się do woli narodu, jeśli nie zgadzał się $\mathrm{z}$ ustawą. Referendum musiało być też zarządzone, jeśli zażądała tego ${ }^{1 / 3}$ posłów lub ${ }^{1 / 20}$ obywateli uprawnionych do głosowania. Wynik był wiążący dla władz. Referendum pełniło również funkcję arbitrażu całego narodu w celu obrony partykularnych interesów. Wprowadzając ten mechanizm, wzorowano się na Szwajcarii oraz kierowano koniecznością ograniczenia roli Prus. Twórcy niemieckiej konstytucji wybrali zatem drogę przeciwną do Francji z okresu III Republiki, gdzie obstawano przy demokracji przedstawicielskiej, bez form bezpośrednich ${ }^{59}$.

\subsubsection{Władza wykonawcza}

\subsubsection{Prezydent Rzeszy}

Na czele państwa stał prezydent wybierany na siedmioletnią kadencję w wyborach bezpośrednich i powszechnych ${ }^{60}$. Prezydentem mógł

\footnotetext{
59 Zob. G. Górski, S. Salmonowicz, op.cit., s. 608.

${ }^{60}$ Kadencja siedmioletnia nawiązuje do ustroju francuskiego, a wybory powszechne do rozwiązania Stanów Zjednoczonych. W obu przypadkach możliwa była reelekcja, co również przejęto. Wybory powszechne zostały wprowadzone, aby zapobiec „absolutyzmowi parlamentarnemu”.
} 
zostać każdy obywatel, który ukończył 35 lat. Długa kadencja i możliwość reelekcji czyniły z prezydenta główną instytucję federalną. Republika Weimarska jest przykładem państwa, w którym reforma systemu ustrojowego po I wojnie światowej nie obrała kierunku przewagi parlamentu nad rządem, ale ugruntowała silną pozycję głowy państwa ${ }^{61}$. Instytucja prezydenta nie wykluczała $z$ założenia sprawnego funkcjonowania parlamentu. System nazywany był prezydencką republiką parlamentarną i zakładał równowagę władz.

Do kompetencji prezydenta należały: reprezentowanie państwa na zewnątrz, zawieranie umów międzynarodowych, stanie na straży poszanowania prawa wewnętrznego, wypowiadanie wojny i zawieranie pokoju za zgodą Sejmu czy stosowanie prawa łaski. Prezydent mógł też, na mocy uprawnień przyznanych mu przez konstytucję (art. 48), zmusić przy użyciu sił zbrojnych kraje związkowe do przestrzegania postanowień konstytucji, jeśli kraje te uchylały się od tego obowiązku. Prezydent był również najwyższym zwierzchnikiem armii i floty Rzeszy. Dysponował także znacznymi uprawnieniami w zakresie funkcjonowania parlamentu (prawo rozwiązania Sejmu ${ }^{62}$ ) i ustawodawstwa (prawo zarządzenia referendum ludowego). Nie przysługiwało mu prawo weta zawieszającego, mógł jednak poddać każdą ustawę pod referendum ${ }^{63}$. Do niego wreszcie należało prawo do mianowania i odwoływania kanclerza, a na jego wniosek - mini-

${ }^{61}$ Zob. I.A. Lewin, Sowriemiennaja nauka gosudarstwiennego prawa, Moskwa 1960, s. 332-333, cyt. za: J. Stembrowicz,op.cit. Przewaga parlamentu w pozostałych państwach wzorowana była na ustroju Francji. Zob. J. Stembrowicz, op.cit., s. 84-93.

${ }^{62}$ Decyzja o rozwiązaniu wymagała uzasadnienia, gdyż konstytucja zabraniała rozwiązania Sejmu więcej niż jeden raz z tego samego powodu (art. 25). W praktyce zakaz ten został złamany w 1932 roku. Zob. szerzej J. Stembrowicz, op.cit., s. 98-99.

${ }^{63}$ Możliwość odwołania się do głosu społeczeństwa niwelowała brak możliwości wniesienia weta, dzięki czemu pozycja prezydenta pozostawała silna. Nie wybrano modelu amerykańskiego, gdzie prezydent wyposażony jest w prawo weta. Uważa się, że instrument referendum w ręku prezydenta Republiki Weimarskiej stanowił przejaw „prezydencjalizmu plebiscytarnego”, czyli sytuacji, kiedy prezydent sięga do prawa zarządzenia referendum w celu potwierdzenia zaufania do swojej osoby (podobnie instytucję tę wykorzystywał Napoleon). Zob. ibidem, s. 95, przyp. 15. 
strów oraz innych urzędników Rzeszy. Osoba kanclerza co do zasady powinna być akceptowana przez większość parlamentarną.

Wspomniany już kontrowersyjny art. 48 konstytucji przyznawał prezydentowi prerogatywę pozwalającą wydawać zarządzenia wkraczające w materię ustawową i zmieniające ustawy ${ }^{64}$, co umożliwiało tzw. rządy pozaparlamentarne ${ }^{65}$. W doktrynie uprawnienie to nazywane jest „legalną dyktaturą”. Wydane akty, $z$ uwagi na to, że zastępowały prawodawczą rolę parlamentu, powinny być przedstawiane Sejmowi, a na jego żądanie uchylone. Omawiany przepis dawał także możliwość przejściowego zawieszenia zupełnie lub częściowo niektórych konstytucyjnych praw i wolności, co jest uważaneza jedną z przyczyn upadku Republiki Weimarskiej. Przepis art. 48 od początku swego obowiązywania był wykorzystywany wbrew legislacyjnym założeniom i zamiast zapewniać bezpieczeństwo państwu, służył celom politycznym ${ }^{66}$. Ten instrument wyjątkowy stał się standardowym sposobem sprawowania władzy wykonawczej po 1925 roku, co paraliżowało parlament ${ }^{67}$.

Ważnym zagadnieniem jest odpowiedzialność prezydenta. Wydawane przez niego rozporządzenia i zarządzenia wymagały kontrasygnaty kanclerza lub odpowiedniego ministra. Taki stan rzeczy uwalniał prezydenta od odpowiedzialności politycznej za te akty ${ }^{68}$. Identyczne rozwiązanie obowiązywało we francuskiej konstytucji z 1875 roku. Jednak mógł on być pociągnięty do odpowiedzialności prawnej (konstytucyjnej) przed Najwyższym Trybunałem Państwowym Rzeszy na mocy decyzji Sejmu Rzeszy (na wniosek przynajmniej 100 posłów). Konstytucja dawała też możliwość usunięcia

64 Szacuje się, że w oparciu o art. 48 wydano ok. 250 aktów normatywnych. Już do 1924 roku Fryderyk Ebert wydał 134 rozporządzenia wyjątkowe. Zob. C. von Krockow, DieDeutschen in ihremJahrhundert 1890-1990, Hamburg 1992, s. 135.

${ }^{65}$ Zob. szerzej o drodze od parlamentaryzmu do dyktatury opartej na art. 48 konstytucji: E. Eyck, Geschichte der Weimarer Republik, Bd. 2, Von der Konferenz von Locarno bis zu Hitlers Machtübernahme, Erlenbach-Zürich 1972 , s. 319-347.

${ }^{66}$ Zob. szerzej J. Stembrowicz, op.cit., s. 99-100.

67 Zob. T. Mergel, op.cit., s. 428-429.

68 Uważane jest to za podstawową zasadę rządów parlamentarno-gabinetowych. Zob. K. Krasowski et al., op.cit., s. 281. 
prezydenta. W przypadku utraty zaufania Sejmu, na skutek wniosku popartego decyzją $2 / 3$ ogólnej liczby posłów i większości obywateli w głosowaniu powszechnym, prezydent mógł zostać odwołany z urzędu. Sama uchwała Sejmu zawieszała sprawowanie urzędu prezydenta, a referendum przesądzało o utracie bądź utrzymaniu stanowiska. Gdyby jednak wniosek Sejmu został odrzucony w referendum, wiązało się to $z$ rozwiązaniem Sejmu i koniecznością rozpisania nowych wyborów, a dzień referendum stawał się początkiem nowej kadencji prezydenta ${ }^{69}$.

\subsubsection{Kanclerz i rząd Rzeszy}

Obok prezydenta władzę wykonawczą sprawował rząd Rzeszy z kanclerzem na czele. Należy zaznaczyć, że pozycja kanclerza była bardzo znacząca, w opinii Edmunda Kleina silniejsza niż pozycja premiera w Wielkiej Brytanii ${ }^{70}$. Kolegialny rząd, w którym ministrowie upoważnieni byli do kierowania resortami i ponosili odpowiedzialność polityczną, a nie tylko służyli głosem doradczym kanclerzowi, stanowił nową jakość ustrojową względem II Rzeszy ${ }^{71}$. Odpowiedzialności politycznej podlegał także kanclerz w imieniu całego rządu ${ }^{72}$. W przypadku otrzymania wotum nieufności rząd zmuszony był podać się do dymisji ${ }^{73}$. Prezydent mógł jednak utrzymać rząd przez rozwiązanie Sejmu i rozpisanie nowych wyborów. Kanclerz i ministrowie podlegali też odpowiedzialności prawnej. Oskarżenie formułował Sejm Rzeszy, a sądził Najwyższy Trybunał Państwowy Rzeszy.

69 To ciekawe i nowatorskie rozwiązanie wprowadzono, aby Sejm nie nadużywał uprawnienia do egzekwowania odpowiedzialności politycznej prezydenta. Wszak pomyślny dla prezydenta wynik referendum przedłużał, i tak długą, kadencję na kolejne siedem lat.

${ }^{70}$ Zob. E. Klein, Powszechna historia państwa i prawa, Wrocław 2003, s. 718. Wynikało to $z$ tradycji ustrojowej II Rzeszy.

${ }^{71}$ Zob. J. Stembrowicz, op.cit., s. 94-95.

${ }^{72}$ Odpowiedzialność tę kanclerz ponosił wobec prezydenta, podobnie jak w II Rzeszy wobec cesarza.

${ }^{73}$ Konstytucja weimarska jest jedną z pierwszych, obok Konstytucji marcowej z 1921 roku, która wprowadza tę zasadę. 
Do kompetencji rządu należał przede wszystkim nadzór nad aparatem administracyjnym. Wyłącznym uprawnieniem kanclerza było wytyczanie głównych kierunków w polityce Rzeszy (art. 56). Decydował on także o składzie personalnym rządu i kierował jego czynnościami. Kanclerz zastępował też prezydenta, gdy ten w wyjątkowych okolicznościach nie mógł sprawować urzędu.

\subsubsection{Władza sądownicza}

Struktura sądownictwa nie zmieniła się w sposób znaczący. Na poziomie federacji funkcjonowały trzy sądy: Sąd Rzeszy, Najwyższy Trybunał Państwowy Rzeszy i Sąd Administracyjny Rzeszy. Najwyższy organ sądowniczy to Sąd Rzeszy, będący sądem apelacyjnym. Kompetencje Najwyższego Trybunału Państwowego Rzeszy w dziedzinie rozstrzygania spraw odpowiedzialności konstytucyjnej urzędników opisano powyżej. Jurysdykcję w krajach związkowych sprawowały sądy powszechne i sądy administracyjne ${ }^{74}$. Te ostatnie stanowiły novum ustrojowe. Koncepcja sądownictwa administracyjnego wykształciła się w dużej mierze we Francji, gdzie funkcje najwyższego sądu administracyjnego pełniła Rada Stanu ${ }^{75}$. Sądy te powołane zostały w celu ochrony praw obywatelskich przed nadużyciami władz państwowych. Nowym uprawnieniem sądów było również prawo badania zgodności ustaw $z$ konstytucją ${ }^{76}$. Sędziowie powoływani byli dożywotnio, jednak mogli być przeniesieni w stan spoczynku na mocy orzeczenia sadowego. Silna pozycja sędziów bywała nadużywana do propagowania tendencji monarchistycznych ${ }^{77}$.

${ }^{74}$ Pojawiały się obawy, że w przypadku osłabienia demokracji, sądy administracyjne uzależnią się od władzy i nie będą w stanie skutecznie bronić obywateli. Taka sytuacja spotkała francuską Radę Stanu za czasów Konsulatu.

75 Zob. G. Górski, S. Salmonowicz, op.cit., s. 610.

${ }^{76} \mathrm{~W}$ toku prac nad konstytucją zastanawiano się, czy przyznać sądom prawo badania konstytucyjności ustaw (model amerykański), czy takie uprawnienie wykluczyć (model francuski). Podobne dylematy pojawiały się w innych krajach „nowej” demokracji.

77 Gustaw Radbruch stwierdził nawet, że Republika Weimarska była „państwem wojny pomiędzy narodem a władzą sądowniczą”. Zob. G.A. Craig, op.cit., s. $420-421$. 


\section{Kryzys Republiki Weimarskiej i droga ku III Rzeszy Niemieckiej}

Wśród głównych przyczyn upadku Republiki Weimarskiej wymienia się przede wszystkim dalece ingerujące w jej skład terytorialny postanowienia wersalskie. Niemcy zostały pozbawione Alzacji, Lotaryngii, Wielkopolski, Pomorza Gdańskiego, a także drobnych terytoriów na rzecz Belgii, Czechosłowacji i Litwy. O przynależności Szlezwiku, Warmii i Mazur oraz Górnego Śląska miały zadecydować plebiscyty. Nadrenia pozostała strefą zdemilitaryzowaną i okupowaną przez siły Ententy. Na gospodarkę niemiecką spadł ogromny ciężar zobowiązań finansowych wynikających z konieczności spłacenia reparacji wojennych. Postanowienia te uznano za „dyktat wersalski”, pojawiły się nastroje odwetowe. Pokój zawarty po I wojnie światowej nie miał charakteru kompromisu. Jego warunki i późniejsze konsekwencje nazywane są „niekończącym się łańcuchem upokorzeń"78. Winą za taki stan rzeczy społeczeństwo obarczało nowy ustrój demokratyczny. Po wojnie powszechne było również społeczne przekonanie, że Niemcy nie poniosły militarnej klęski. Jest to stwierdzenie poniekąd słuszne, bowiem do chwili zakończenia zmagań wojennych na terytorium Niemiec nie wkroczyły żadne obce siły zbrojne. Ogromny wpływ na odejście od demokracji miał też światowy kryzys ekonomiczny ${ }^{79}$.

Zła sytuacja gospodarcza i kryzysy rządowe nastawiały społeczeństwo negatywnie do demokratycznego systemu rządów. Wybór na prezydenta Paula von Hindenburga był wyrazem skłaniania się nastrojów społecznych do poglądów radykalnych, prawicowych. Po wygranych przez NSDAP wyborach, 31 stycznia 1933 roku Hindenburg powierzył urząd kanclerza Adolfowi Hitlerowi. Nowy parlament uchwalił ustawę o pełnomocnictwach dla rządu, która dawała

${ }^{78}$ H. Schulze, op.cit., s. 257.

79 O kryzysie ekonomicznym i stosunkach wewnętrznych zob. szerzej: A. Radziwiłł, W. Roszkowski, Historia 1871-1939, Warszawa 2004, s. 236-237; H. Schulze, op.cit., s. 258-259; A. Tooze, The German National Economy in an Era of Crisis and War (1917-1945), w: The Oxford Handbook, s. 400-419. 
prawo wydawania ustaw, nawet jeśli ich przepisy były sprzeczne $\mathrm{z}$ konstytucją. To, $\mathrm{w}$ połączeniu $\mathrm{z}$ rozporządzeniem prezydenta o zawieszeniu niektórych praw i wolności obywatelskich, dawało Hitlerowi władzę niemal dyktatorską. Oznacza to faktyczny koniec Republiki Weimarskiej ${ }^{80}$, a początek nowego rozdziału w historii Niemiec - III Rzeszy Niemieckiej.

„Jest paradoksem, że historia Republiki Weimarskiej - jest równocześnie historią NSDAP, że najbardziej demokratyczny w historii Niemiec system rządów parlamentarnych stworzył narodowym socjalistom możliwość objęcia władzy. Fakt ten [...] umożliwił powstanie państwa totalitarnego w najbardziej nieludzkim wydaniu" ${ }^{81}$.

\section{STRESZCZENIE}

Rozwiązania prawnoustrojowe Republiki Weimarskiej w perspektywie historycznej i porównawczej

Zasadniczym celem artykułu jest przedstawienie ukształtowania mechanizmów ustrojowych przyjętych w konstytucji Republiki Weimarskiej. Konstytucja ta wyróżnia się na tle innych europejskich unormowań. Jej główną wartością jest twórcze wykorzystanie dorobku innych państw oraz wprowadzenie nowatorskich rozwiązań. To w szerszej perspektywie doprowadziło do przejęcia postanowień niemieckiej konstytucji w kilku państwach, przede wszystkim w republikach bałtyckich. Konstytucja weimarska historycznie odrywa się od wcześniejszych tradycji monarchicznych. Wprowadza przy tym nową jakość do europejskiego konstytucjonalizmu. Istotnym problemem było stosowanie postanowień konstytucji $\mathrm{w}$ praktyce, bowiem zauważalne były tendencje do przywrócenia silnej władzy jednostki, co w połączeniu z kryzysem ekonomicznym otworzyło drogę do władzy nazistom.

Słowa kluczowe: Republika Weimarska, niemiecki konstytucjonalizm, historia ustroju państwa, konstytucyjne prawo porównawcze.

80 Jak zaznaczono wcześniej, formalnie konstytucja Rzeszy Niemieckiej dalej obowiązywała.

${ }^{81}$ K. Krasowski et al., op.cit., s. 284. 


\section{SUMMARY}

Constitutional aspects of the Weimar Republic in the historical and comparative perspective

The history of the Weimar Republic begun in last months of World War I. After war the new constitution was enacted. The name of a state: "Weimar Republic" is given by historians. The main purpose of this article is to present political system of Republic in the perspective of comparative law and history of law. In the history of forms of government in the interwar period, there is distinction between two categories "old" and "new" democratic political systems. The Weimar Republic belong to "new" category. It cause some dissimilarities and practical problems (e.g. during economic crisis). The paper presents characteristic of constitution, general principles, etc. Very important to emphasize are elements of direct democracy (referendum). Constitution used achievements of other countries, especially from French Third Republic (parliamentary republic), United States of America (presidential system, federal government) and United Kingdom. The article consider territorial structure, constitutional authority (legislature, executive and judiciary) and its historical basis and comparison with another examples. In addition, there are presented some unique issues, like political responsibility of the president, or administrative courts. There are opinions, that the Weimar constitution was the most progressive in the interbellum period.

Keywords: Weimar Republic, German constitutionalism, history of political systems, constitutional comparative law.

\section{BIBLIOGRAFIA}

Baszkiewicz J., Powszechna historia ustrojów państwowych, Gdańsk 2007. Banaszak B., Porównawcze prawo konstytucyjne współczesnych państw demokratycznych, Warszawa 2012.

Bryce J., Constitutions, Oxford 1905.

Craig G.A., Germany 1866-1945, Oxford 1981.

Czubiński A., Wybrane problemy historii Niemiec XIX i XX wieku, Poznań 1992.

Dziadzio A., Koncepcja państwa prawa $w$ XIX w. Idea i rzeczywistość, „Czasopismo Prawno-Historyczne” 2005, t. Tom 57. 
Eyck E., Geschichte der Weimarer Republik, Bd. 2:Von der Konferenz von Locarno bis zu Hitlers Machtübernahme, Erlenbach-Zürich 1972.

Górski G., Salmonowicz S., Historia ustrojów państw, Warszawa 2001. Grodziski S., Porównawcza historia ustrojów państwowych, Kraków 1998. Gulczyński A. et al., Historia państwa i prawa. Wybór tekstów źródłowych, Poznań 2002.

Jaworski I., Zarys powszechnej historii państwa i prawa, Warszawa 1996. Kamińska K., Gaca A., Historia powszechna ustrojów państwowych, Toruń 2011.

Kierończyk P., Państwo łotewskie. Geneza i ustrój konstytucyjny, Gdańsk 2008.

Klein E., Powszechna historia państwa i prawa, Wrocław 2003.

Klementowski M., Powszecha historia ustroju, Warszawa 2012.

Kotłowski T., Historia Republiki Weimarskiej (1919-1933), Poznań 1991.

Krasowski K. et al., Historia ustroju państwa, Poznań 2002.

Krockow C., Die Deutschen in ihrem Jahrhundert 1890-1990, Hamburg 1992.

Lewin I.A., Sowriemiennaja nauka gosudarstwiennego prawa, Moskwa 1960.

Ludwikowski R.R., Prawo konstytucyjne porównawcze, Toruń 2000.

Łossowski P., Kraje battyckie na drodze od demokracji parlamentarnej do dyktatury (1918-1934), Wrocław-Warszawa-Kraków-Gdańsk 1972.

Maciejewski T., Historia powszechna ustroju i prawa, Warszawa 2011.

Mann G., Niemieckie dzieje w XIX i XX wieku, tłum. A.Kopacki, Olsztyn 2007.

Mergel T., Dictatorship and Democracy (1918-1939), w: The Oxford Handbook of Modern German History, red. H.W. Smith, Oxford 2011.

Paluszyński T., Historia Niemiec i państw niemieckich. Zarys dziejów politycznych, Poznań 2006.

Peukert D., Republika Weimarska. Lata kryzysu klasycznego modernizmu, tłum. B.Ostrowska, Warszawa 2005.

Radziwiłł A., Roszkowski W., Historia 1871-1939, Warszawa 2004.

Salmonowicz S., Prusy. Dzieje państwa i społeczeństwa, Warszawa 2004.

Schulze H., Państwo i naród $w$ dziejach Europy, tłum. D. Lachowska, Warszawa 2012.

Sczaniecki M., Powszechna historia państwa i prawa, Warszawa 2003.

Stembrowicz J., Rzą $w$ systemie parlamentarnym, Warszawa 1982.

Švābe A., Agrārā reforma, w: Latvija 20 gados, Ryga 1938.

Tokarczyk R., Wprowadzenie do komparatystyki prawniczej, Lublin 1996. Tooze A., The German National Economy in an Era of Crisis and War (1917-1945), w: The Oxford Handbook of Modern German History, red. H.W. Smith, Oxford 2011. 
Wąsicki J., Rzesza a kraje niemieckie w 1914-1949, Poznań 1977.

Wąsowicz M., Historia ustroju państw zachodu. Zarys wykładu, Warszawa 2007.

WeitzE.D., Niemcy weimarskie. Nadzieje i tragedia, tłum. A. Czwojdrak, Kraków 2011. 
